\title{
Knowledge and Practice of Drinking Safe Water Among the Community People of Horintana, Khulna
}

\author{
*F Ferdaus
}

\begin{abstract}
Background: Water is basic human right, most precious resource for economy and health. Drinking water and sanitation is a fundamental health service. The health of a person largely depends on its quality and quantity of safe water. Water must be safe and wholesome. But unfortunately the problem of water pollution has now become a burning question.
\end{abstract}

Objective: To explore the knowledge and practice of drinking safe water among the community people.

Method: This was a descriptive type of cross-sectional study conducted at Horintana, Khulna, during the period from January 2018 to April 2018 to assess the Knowledge and practice of drinking safe water among the villagers. The respondents were adult population of the community.

Result: Most of the respondents were in 30-44 years age group, (53.64\%) and 15-29 years age group $(31.36 \%)$. Majority of the respondents were female (84.55\%). Majority of villagers drank tube well water (93.64\%). $81.36 \%$ of the respondents knew about safe sources of drinking water. $14(6.36 \%)$ respondents, who used water other than tube well water applied purification methods. A large portion of respondents (14.09\%) did not know about the water borne diseases. Among the water borne diseases they had suffered, most prevalent diseases were diarrheal diseases (57.63\%) and parasitic infestations (16.66\%). In most cases, treatment providers were MBBS doctors $(64.23 \%)$.

Conclusion: In conclusion, the study revealed that the knowledge and practice of safe drinking water among the rural people is now satisfactory. But the matter of great sorrow is that, the socio-economic condition and educational status of people is hampering towards the good health.

Key Words: Knowledge, Practice, Safe drinking water

\section{Introduction}

Water is the essence of life and basic human right, essential to all and for sustainable development. It is known that drinking water is our most precious resource for our economy, our daily lives and to the health of our environment. ${ }^{1}$ Drinking water and sanitation is a fundamental health service without which there cannot be any improvement. Drinking water and sanitation inadequacies hinder economic and social development, constitute a major hurdle to poverty alleviation and inevitably lead to environmental degradation. ${ }^{2}$ Water must be safe and wholesome. It should be easily accessible, adequate in quantity, free from contamination, safe and readily available throughout the year. ${ }^{3}$ Positive health is not possible without safe water. But unfortunately the problem of water pollution has now become a burning question. Much of ill health that affect humanity is due to lack of safe water supply, particularly in the developing country like ours. ${ }^{4}$ The incidence of water borne diseases like typhoid, paratyphoid, diarrhea, dysentery, cholera, parasitic infestations etc. are increasing day by day.

*Dr. Farhana Ferdaus, Assistant Professor and Head, Community Medicine, Khulna City Medical College

Mobile: 01744247421, e-mail.farhanasumi87@yahoo.com

*Corresponding Author

Date of submission: 02.02.2019 Date of acceptance: 13.03.2019

AKMMC J 2019; 10(2) : 105-109 
These problems can be drastically reduced by raising awareness among people and providing them safe drinking water. ${ }^{5}$

Water is the basis of life and blue arteries of the earth. Everyone in the environment depends on fresh water to survive. ${ }^{6}$ Villagers are not conscious about the importance of drinking safe water. As a result, they are suffering from various water borne diseases. ${ }^{6}$ It is an urgent need to educate them in order to develop the habit of drinking safe water. They should be encouraged to drink water from safe sources and purify water before drinking by various methods of water purification such as boiling, chlorination, filtration etc. when safe sources are not available. Because- "water is the blood in our veins". ${ }^{7}$ It is not possible to develop the habit of drinking safe water in $100 \%$ people but the percentage can be increased by raising consciousness among them about the importance of drinking safe water and providing them information about various methods of water purification. Because they must be aware of that- "Water is the oil of 21 century". ${ }^{8}$ For this purpose a study has been carried out at Horintana, Khulna

This study is not enough to completely assess the present condition of the habit of drinking safe water among the people of whole country as it has been carried out in a small community among small number of people. So it does not reflect the actual scenario of the country. But it creates a scope to conduct repeated study in this field. The quality of drinking-water is a powerful environmental determinant of health. ${ }^{9}$ Drinking-water quality management has been a key pillar of primary prevention for over one-and-a-half centuries and it continues to be the foundation for the prevention and control of water borne diseases. To ensure availability of safe drinking water supply, reliance has to be placed on regular bacteriological analysis to assess portability and to determine the best course of action for protecting the population against waterborne diseases (Ramteke \& Bhattaacherjee, 1992). In 1998, the National Policy for Safe Drinking Water Supply and Sanitation (NPSWSS) was published. The main objective of this policy is to improve public health and produce a safe environment by reducing water borne disease and contamination. ${ }^{10}$

\section{Methodology}

It is a community based cross sectional study conducted during January 2018 in Horintana, Khulna. The study population was all the individual irrespective to their sex, age starting from 15 years. It was possible to collect data from 220 respondents during the scheduled period of data collection. Structured questionnaires were prepared, which include the basic sociodemographic profile, knowledge and practice questions regarding drinking water of households in the rural communities of the study area. The questionnaire was pre-tested in few selected household. The pretest was conducted near the study area which had similar characteristics to the areas where the actual study was carried out. A purposive type of nonprobability sampling is applied, therefore sample size of the study was finalized to 220 respondents.

\section{Result}

Table-1: Distribution of respondents by age

\begin{tabular}{lcc}
\hline Age (years) & No. of respondents & Percentage \\
\hline $15-29$ & 69 & $31.36 \%$ \\
$30-44$ & 118 & $53.64 \%$ \\
$45-59$ & 26 & $11.81 \%$ \\
60 and above & 07 & $3.18 \%$ \\
Total & 220 & $100 \%$ \\
\hline
\end{tabular}

It was found that $118(53.64 \%)$ of the respondents were of age group 30-44 and only 07 (3.18\%) of the respondents were of age group 60 and above.

Table-2: Respondents by source of water

\begin{tabular}{lcc}
\hline Source of water & No. of respondents & Percentage \\
\hline Tube well & 206 & $93.64 \%$ \\
Pond & 14 & $6.36 \%$ \\
River & 00 & $00 \%$ \\
Total & 220 & $100 \%$ \\
\hline
\end{tabular}

It was found that most of the respondents 206 $(93.64 \%)$ drink water from tube well. 
Table-3: Respondents by knowledge about safe source of drinking water

\begin{tabular}{lcc}
\hline $\begin{array}{l}\text { Knowledge of } \\
\text { safe source of } \\
\text { drinking water }\end{array}$ & No. of respondents & Percentage \\
\hline Yes & 179 & $81.36 \%$ \\
No & 41 & $18.64 \%$ \\
Total & 220 & $100 \%$ \\
\hline
\end{tabular}

It was found that $179(81.36 \%)$ respondents had knowledge of safe source of drinking water and 41 (18.64\%) respondents had no knowledge of safe source of drinking water

Table-4: Respondents suffering from water borne diseases in last 12 months

\begin{tabular}{lcc}
\hline Type of disease & No. of respondents & Percentage \\
\hline Diarrhea & 90 & $62.5 \%$ \\
Jaundice & 18 & $12.5 \%$ \\
Cholera & 28 & $19.44 \%$ \\
Hookworm infestation & 08 & $5.55 \%$ \\
Total & 144 & $100 \%$ \\
\hline
\end{tabular}

Table shows that most of the respondents 90 $(62.5 \%)$ suffered from diarrhea and only $8(5.55 \%)$ suffered from hookworm infestation.

Table-5: Respondents regarding treatment providers during last episode of disease

\begin{tabular}{lcc}
\hline Treatment provider & No. of respondents & Percentage \\
\hline MBBS doctor & 79 & $64.23 \%$ \\
Quack & 28 & $22.76 \%$ \\
Kabiraj & 11 & $8.94 \%$ \\
Specialist & 05 & $4.07 \%$ \\
Total & 123 & $100 \%$ \\
\hline
\end{tabular}

Table shows that most of the respondents 79 (64.23\%) received treatment from MBBS doctor and only 5 $(4.07 \%)$ respondents received treatment from specialist during last episode of water borne disease.

\section{Discussion}

In this study, total sample was 220 respondents. Among them, 118 respondents were in between 3044 years age group $(53.64 \%) \& 15-29$ years group (3 1.36\%). Female were $(84.55 \%)$ \& male were $(15.46 \%)$. Regarding educational status, highest percentage was observed in secondary level education $(28.64 \%)$, followed by primary level education $(25 \%)$ and illiterate $(21.36 \%)$, which reflected that females were still lagging behind in case of educational status. ${ }^{11}$ More than $80 \%$ $(81.82 \%)$ of the study population were housewives as information from those who were dealing with collecting water \& providing it to the family member. It was proved from the study that most of the villagers of modern age had exposure to media $(71.36 \%)$ and who had no exposure were of small portion. Observation regarding type of family revealed nuclear family holding the top most position $(68.65 \%)$, followed by Join family $(26.82 \%)$ \& expended family $(4.5 \%)$. It gave an idea that, the social trend of the country has been changed. ${ }^{12}$ About $43.36 \%$ of the respondents were of lower middle class group, upper middle class and upper class were $19.54 \%, 28.18 \%$ \& $5.90 \%$ respectively, the distribution of class was based on monthly income \& others possessions. In the year 1993 , it was discovered that ground water was the source of drinking water for $97 \%$ of rural population. ${ }^{13}$ In this study 206 (93.64\%) respondents used tube well as their source of drinking water. It was revealed that majority $(81.36 \%)$ of the population had knowledge about safe sources of drinking water \& rest $(18.64 \%)$ did not have. Among the respondents, about $85.91 \%$ had knowledge regarding disease caused by unsafe drinking water, this is undoubtedly a good response from them. It was found that among the respondents who suffered from water borne diseases $63.89 \%$ suffered once in last 12 months. During the disease process, about $85.42 \%$ of the sufferer received treatment \& $14.58 \%$ waited for self-limitation of the disease which proves that the people of rural community are now a days aware about their own health. Educated people possessed much more a sources of drinking water that was observed $100 \%$ respondents having secondary level education or more drank tube well water, whereas $92 \%$ people with primary level education, $78 \%$ people with no education used tube well as the source of drinking water. 
$100 \%$ of the teachers and service holders used tube well water for drinking, among housewives the percentage was $97 \%$, in contrast to pond water consumers were maximum in farmers $(42 \%)$ and day laborers (40\%). It was also noticed that among illiterate people only $22 \%$ knew what are the water borne diseases, in people having primary and secondary education level the percentages were $65 \%$ and $92 \%$ respectively. $100 \%$ people having education SSC or more knew about water borne diseases, which was obvious. $100 \%$ people of upper middle class group had knowledge about water borne diseases, the percentage was $27 \%$ in lower class group and $36 \%$ in lower middle class group. It revealed that socio-economic condition has a great effect on the health status. ${ }^{14}$

\section{Conclusion}

The survey was successful and informative enough. From the study investigators have gathered experiences and practical knowledge about the field application of academic knowledge. From the study it was revealed that, awareness regarding drinking safe water is increasing. Most of the villagers (93.64\%) use tube well water as source of drinking water and other use purification methods for safe water while a little population are using unsafe water. Striking fact is that they have little knowledge about use of unsafe water. Education and awareness campaign may be powerful tool for public health interventions. Planned awareness of safety measures especially to uneducated and rural women along with relative empowerment of woman in household affairs would be the key tools of success. Print \& electronic media can be used to play a role in sensitizing and informing people about health hazards from unsafe drinking water.

\section{Acknowledgement}

The authors gratefully acknowledge the technical support provided by Department of Community Medicine, Khulna City Medical College, Khulna

Conflict of Interest: Nothing to declare.

\section{References}

1. World Health Organization (WHO) (2004). Water, sanitation and hygiene links to health, facts and figures. Geneva. Available at: http://www.who.int/ water_sanitation_health/ en/factsfigures04.pdf. Assessed 4 February 2014.

2. Choudury N, Hossain MA. Exploring the current Status of Sanitary latrine use in shibpur Upazila, Narsingdi district. BRAC report. 2006.

3. Moe CL, Rheingans RD. Global challenges in water, sanitation and health. J Water Health. 2006; 4(Suppl 1): 41-57.

4. Progress on drinking water and sanitation 2012 update: JMPreport2012. Available at: http://www.unicef.org/ media/ files/ JMPreport 2012.pdf. Assessed on $8^{\text {th }}$ February 2014.

5. WHO/UNICEF Joint monitoring programme for water supply and sanitation. Meeting the MDG drinking water and sanitation target: a mid-term assessment of progress. World Health Organization, Geneva and United Nations Childrens Fund, New York; 2004. Available at: http://www.who. int/ water_sanitation health/monitoring/jmpfinal.pdf. Assessed on $12^{\text {th }}$ February 2014.

6. Howard G, Jahnel J, Frimmel FH, McChesney $\mathrm{D}$, Reed B, Schijven J, et al. Human excreta and sanitation Potential hazards and information Needs. World Health Organization. London UK. IWA Publication:2006.

7. Pandve HT. Environmental sanitation: an ignored issue in India. Indian Journal of Occupational Environmental Medication. 2008;12(1): 40. Available at: http:// www. ijoem. com/ article. asp. Assessed on 15th Febrary 2014.

8. Tamilnadu: Main source of drinking water, 2011. Available at: http://www.census.tn.nic.in/ HLO_Datasheet_Final/ HLO_ Datasheet Drinking_Water_Page 1.pdf. Assessed on $18^{\bar{t}}$ February 2014. 
9. Bilas R, Singh RP. Rural water supply and the problem of health in village India, case of the Varanasi district. Geogr Med. 1981;11: 65-85.

10. Kang G, Ramakrishna BS, Daniel J, Mathan M, Mathan VI. Epidemiological and laboratory investigations of outbreaks of diarrhoea in rural South India: implications for control of disease. Epidemiol Infect. 2001;127:107-12.

11. Tamil Nadu Water Supply and Drainage (TWAD) Board. Guidelines for provision of water supply and hygiene for the village panchayat: book in tamil. Northern Zone, Vellore, Tamil Nadu. Tamil Nadu Water Supply and Drainage Board. Communication and Human Resource Development Division. 2007.
12. Gopal S, Sarkar R, Banda K, Govindarajan J, Harijan BB, Jeyakumar MB. Study of water supply and sanitation practices in India using geographic information systems: some design and other considerations in a village setting. Indian J Med Res. 2009; 129: 233-41.

13. Swaroop N, Janish A, Fernandez S, Ramakrishna GB, Agrawal T, Ravi S. Access to improved drinking water and sanitation facilities in a rural area of Bangalore urban district; Nat J Res Com Med. 2012; 1(2).

14. Bharti, Malik M, Kumar V, Verma R, Chawla S, Sachdeva S. Knowledge attitude and practices regarding water handling and water quality assessment in a rural block of Haryana. Int J Basic Appl Med Sc. 2013; 3(2): 243-7. 